\title{
A pH-ciklizálás jelentősége az amelogenesisben
}

\author{
DR. RÁCZ RÓBERT*, DR. MARTIN C. STEWARD*,**, DR. PAMELA DENBESTEN***, \\ DR, VARGA GÁBOR*, DR. KERÉMI BEÁTA*
}

\begin{abstract}
A zománcérés folyamatai hisztomorfológiai szinten jól ismertek, de a kristályképződés szabályozása, a háttérben álló molekuláris mechanizmusok még jórészt ismeretlenek. A szájüregi hámból származó ameloblast sejtek irányítják a zománcérést. A mátrixfehérjék szekrécióján és a zománcalkotó ásványi anyagok transzportján kívül a pH-szabályozásnak központi jelentősége van a zománcérésben, ugyanis a kristályképződés nagy mennyiségű $\mathrm{H}^{+}$felszabadulásával jár, amely semlegesítéséhez $\mathrm{HCO}_{3}{ }^{-}$szekréciója szükséges. Az érési fázis alatt kiemelt fontosságú a pH-ciklizálás jelensége, melynek során a szoros sejtkapcsolatok átrendeződése is megfigyelhető. A transzport- és szabályozó folyamatok genetikai vagy környezeti sérülése (pl. dentális fluorózis) a zománc hipomineralizációjához vezet. Ezen folyamatok felderítése céljából létrehoztunk egy funkcionális in vitro modellt. Ennek központi eleme, hogy permeábilis membránra ültetett, differenciáltatott ameloblast eredetű sejtek az ameloblastokra jellemző fehérjemarkereket expresszálják, szoros kapcsolatokat alakítanak ki, funkcionális szempontból polarizáltak, és vektoriális $\mathrm{HCO}_{3}{ }^{-}$szekrécióra képesek. Saját kísérletes munkánk eredményei hozzájárulnak az ameloblast sejtek pH-ciklizálást elősegítő molekuláris mechanizmusának megértéséhez.
\end{abstract}

Kulcsszavak: zománcfejlődés, pH-szabályozás, ameloblast, bikarbonát,

\section{Bevezetés - A zománcképződés folyamatának főbb lépései}

A zománcfejlődés sok tényező összehangolt müködése által szigorúan szabályozott folyamat. Ennek eredményeként az emberi szervezet legjobban mineralizált, legnagyobb szervetlen állománnyal rendelkező (95-96\%) szövete alakul ki. Három fő fázisát különíthetjük el, ezek a preszekretoros, szekretoros és érési fázis $[31,40,56]$. A zománcképzésben az epithelialis eredetű ameloblastok vesznek részt, amelyek a teljes fejődési folyamat során a funkciójukkal szoros összefüggésben, egymást váltva, különböző morfológiai alakokban jelennek meg.

A preszekretoros fázisban az ameloblastok a fogcsíra zománcszervének ektodermális eredetű belső zománchám sejtjeiből differenciálódnak. Közben polarizálttá válnak az egyes sejteket egymáshoz kapcsoló, ún. junkcionális komplexek és a fehérjéket szintetizáló sejtalkotók megjelenésével [31].

A szekretoros ameloblastok magas, oszlopos sejtek, asszimetrikus szerkezettel. A sejtmag és az energiaszolgáltató mitokondriumok a bazális póluson helyezkednek el, míg a fehérjeszintézisben szerepet játszó endoplazmás retikulum és a Golgi-apparátus az apikális, vagy más néven szekretoros póluson található meg. Ezenkívül az apikális póluson a sejt speciális nyúlványa, a Tomes-nyúlvány jelenik meg [28], amely fontos szerepet játszik a zománckristályok - a zománcprizmák és az interprizmatikus állomány - kialakulásában [31]. A szekretoros fázisban a zománc teljes vastagsága kialakul, de az alapállomány még csak kis mértékben mineralizálódott (kb. 30\%), a kristálycsíkok közötti teret egy később lebomló fehérje, az amelogenin tölti ki.

A maturációs, vagy más néven érési fázis megindulásakor az ameloblastok morfológiája megváltozik: magasságuk, fehérjeszintetizáló sejtorganellumaik száma csökken, és a Tomes-nyúlvány is eltünik [31]. Az érési fázisban a maturációs ameloblastok két formája egymásba többször is átalakul [11, 27]. Ezek a fodros felszínű (ruffle-ended) és a sima felszínú (smooth-ended) formák [55]. (1. kép) A fodros felszínú ameloblastok között a szoros sejtkapcsoló struktúrák (tight junction) az apikális pólusnál vannak jelen, elősegítve a jelentős endocitotikus aktivitást. (1. A kép) Ezzel szemben a sima felszínú ameloblastokban kisebb az endocitotikus aktivitás, az apikális szoros záródás pedig bazális irányba épül át. (1. $B$ kép) Az érési fázisban egy adott időben a fodros felszínú sejtalakok teszik ki az ameloblastok közel $70 \%$-át, míg a sima felszínű formák mintegy $20 \%$-ot [31]. A maturációs szakaszban az organikus állomány szinte teljes felszívódása megtörténik, és a kétféle sejtalak váltakozó megjelenésével, az ásványi alkotók intenzív transzportja és beépülése mellett a zománckristályok vastagságbeli növekedésével a zománc eléri végleges kristályosodási (mineralizációs) fokát. 


\section{pH-változás \\ az amelogenesis során a mineralizációs térben}

A kristályképződés folyamán minden egységnyi hidroxiapatit molekula képződése nyolc egység hidrogénion felszabadulással jár együtt, ami jelentősen csökkenti az extracelluláris $\mathrm{pH}-\mathrm{t}$ [56]. A kémiai folyamat a következő:

$$
\begin{gathered}
10 \mathrm{Ca}^{2+}+6 \mathrm{HPO}_{4}^{2-}+ \\
2 \mathrm{H}_{2} \mathrm{O} \leftrightarrow \mathrm{Ca}_{10}\left(\mathrm{PO}_{4}\right)_{6}(\mathrm{OH})_{2}+8 \mathrm{H}^{+}[30]
\end{gathered}
$$

Az ilyen módon savassá váló környezet a kristályképződés gátlásához vezetne [27, 31, 36, 56, 66], ezért szükség van egy megfelelő $\mathrm{pH}$-semlegesítő mechanizmusra. Számos munkacsoport vizsgálta a pH szabályozás jelentőségét [9, 24, 27, 57]. A szekretoros fázisban a mineralizációs térben a pH kb. 7,2. A maturációs fázisban az extracelluláris $\mathrm{pH}$ nagyobb változatosságot mutat, a semlegestöl a gyengén savas $\mathrm{pH}$ között $(6,2-7,2)$ változik [11]. (2. kép) Az érési fázis befejezéséhez közeledve a pH-érték emelkedése figyelhető meg [58]. A semleges, enyhén alkalikus extracelluláris $\mathrm{pH}$ a sima felszínú ameloblastok fázisára jellemző. Az ameloblastok nagyon pontosan kontrollálják az extracelluláris $\mathrm{pH}$-t annak érdekében, hogy a további $\mathrm{Ca}^{2+}$ és $\mathrm{PO}_{4}^{-}$ionok beépülése zavartalan legyen [31], de a szabályozás molekuláris mechanizmusa még nem teljes mértékben ismert.

\section{Az ameloblast sejtek transzportfolyamatai}

A zománcérés során a legfontosabb ásványok és mátrixfehérjék az ameloblastokon keresztül jutnak a zománctérbe: membráncsatornák és transzporter fehérjék közvetítésével, illetve a mátrix-proteinek szekréciója és lebontása, visszavétele az endoszomális/lizoszomális útvonalon keresztül történik.

Sok más szekréciós hámszövethez hasonlóan a paracelluláris utaknak is fontos élettani szerepe lehet az amelogenesis során. A paracelluláris transzport meghatározó struktúrái a szoros sejtkapcsolatok. Ezek azok a struktúrák a többi sejt-sejt kapcsolattípus közül, amelyek a legszorosabb kapcsolódást biztosítják a sejtek számára; mintegy „övszerūen” körbeveszik a sejteket, elzárva az egyrétegú zománchám epithelium apikális és bazolaterális oldalát egymástól. Ez a "gátrendszer" egyes ionok, molekulák koncentráció gradiens szerinti diffúzióját megengedi, másokét ugyanakkor nem. (1. A kép) Egyre több bizonyíték támasztja alá azt az elképzelést, miszerint ezek nem csupán passzív pórusok, hanem dinamikusan szabályozható struktúrák, egyfajta csatornaként müködhetnek [60], így fontos összetevői lehetnek a transzportfolyamatok szabályozásának.

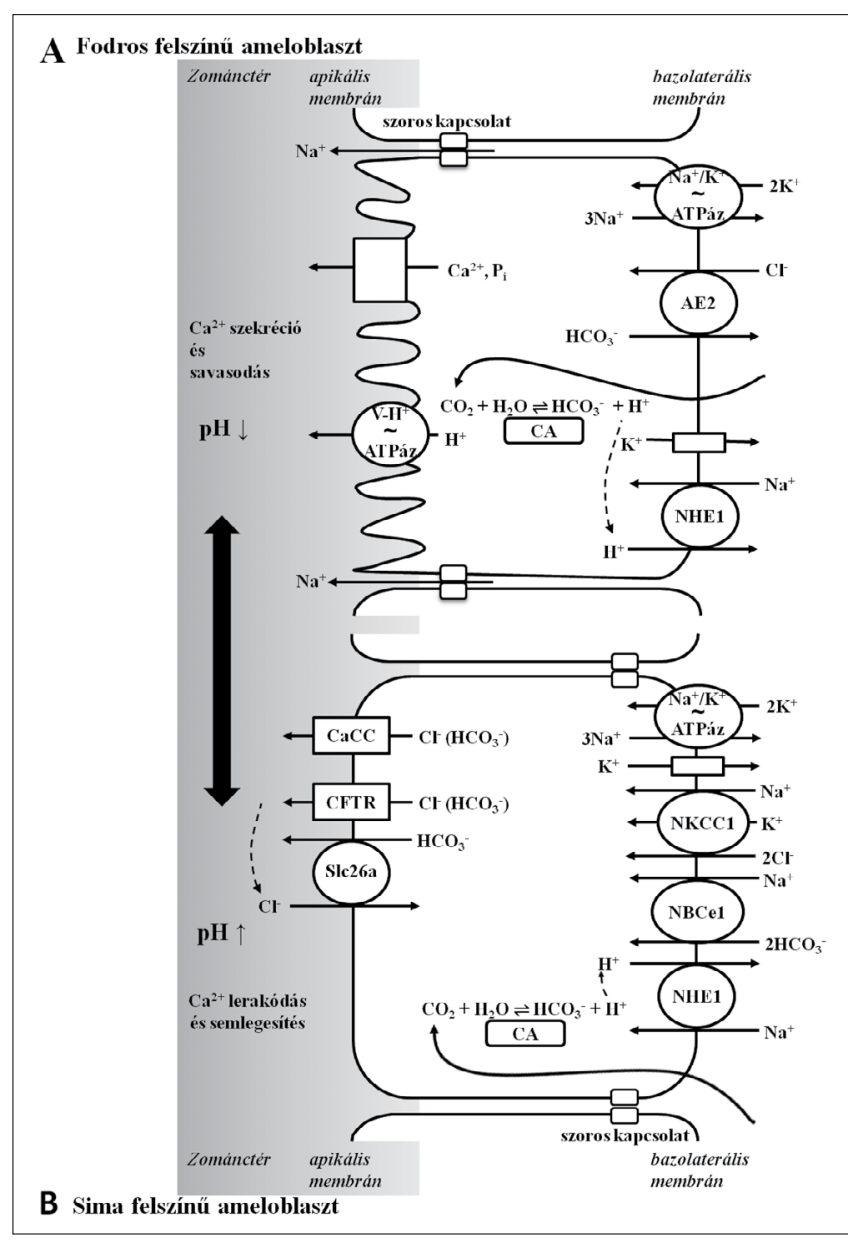

1. kép: Egyszerūsített modell a bikarbonát és elektrolit szekrécióról a fodros felszínú és a sima felszínú ameloblastokban

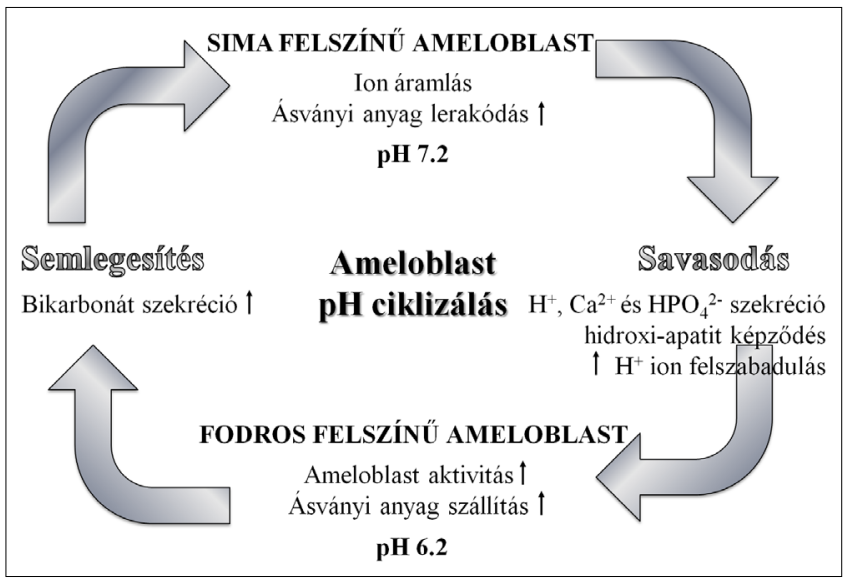

2. kép: pH ciklizálás az ameloblastokban a zománcképzés érési fázisában

\section{Kalcium-transzport}

A zománc szervetlen száraz tömegének többségét alkotó kalcium- és foszfátionok mineralizációs térbe jutása, azaz a papilláris sejtek által körbevett vérerek felöl történő, az ameloblast sejtréteg által végrehajtott transz- 
celluláris transzport módja a mai napig nem teljesen ismert. A zománcérés során a sejteknek képesnek kell lenniük nagy mennyiségü $\mathrm{Ca}^{2+}$ és $\mathrm{PO}_{4}{ }^{3-}$ ion szállítására, oly módon, hogy közben a $\mathrm{Ca}^{2+}$ koncentrációja nem növekedhet meg jelentősen a sejt belsejében. $\mathrm{A} \mathrm{Ca}^{2+}$ megkötésére a citoszólban kelát-képző molekulák szolgálnak. Ilyenek a calmodulin, parvalbumin, calretinin, calcineurin és kétfajta calbindin ( $9 \mathrm{kDa}, 28 \mathrm{kDa})$ fehérje [43]. Az utóbbi évek eredményei emellett az intracelluláris raktárak (endoplazmatikus retikulum $\mathrm{ER}$, mitokondrium) kitüntetett szerepét látszanak igazolni. Lacruz és mtsai kutatásai [41, 42, 44] megerősítették, hogy az ún. „store-operated calcium entry” (SOCE) a fő $\mathrm{Ca}^{2+}$ felvételi mechanizmusa az érési fázisú ameloblast sejteknek (ebben a fázisban a legnagyobb mértékű a $\mathrm{Ca}^{2+}$ transzport és a mineralizáció).

A közelmúltban felmerült egy további, kináz funkcióval rendelkező divalens csatorna, a tranziens receptor potenciál melasztatin-7 kation csatorna (TRPM7) szerepe is a $\mathrm{Ca}^{2+}$ felvételében. Állatkísérletes modellben leírták, hogy a csatorna nem megfelelő müködése egerekben súlyosan hipomineralizált zománc és csontdefektusok kialakulásához vezet, alacsonyabb fokú $\mathrm{Ca}^{2+}$ és magasabb $\mathrm{Mg}^{2+}$ tartalommal [39]. A TRPM7 csatorna zománcérésben játszott pontos szerepe még tisztázatlan.

A Ca ${ }^{2+}$ leadását szolgáló fő transzportmechanizmus az NCKX4 kálium-függő nátrium/kalcium cserélő (antiporter) fehérje lehet a zománctér felé [20]. Ezen kívül a kálium-független nátrium/kalcium-cserélő fehérjék (NCX1-3) és a plazmamembrán $\mathrm{Ca}^{2+}$ ATPáz (PMCA) szerepét is valószínűsítik ezekben a sejtekben a zománcérés különböző stádiumaiban [45, 72], bár még pontos sejten belüli lokalizációjuk nem tisztázott [64], és szerepük, jelentőségük is vita tárgya.

\section{A bikarbonát mint puffer szerepe a szájüregben}

Az élő szervezetekben a legfontosabb puffer rendszer a szénsav/bikarbonát-ion (azaz a $\mathrm{H}_{2} \mathrm{CO}_{3} / \mathrm{HCO}_{3}{ }^{-}$) rendszer. A savközömbösítő szerepén túl, a bikarbonát részt vesz a mucin-molekulák szekréciójának és „kicsomagolásának" szabályozásában [50], valamint a szolubilis adenilát-cikláz (sAC) aktivitásának szabályozásában is [53], amely az intracelluláris ciklikus-AMP szint (cAMP) regulációján keresztül kulcsfontosságú szerepet játszik a különböző sejtfunkciók szabályozásában. A bikarbonát által szabályozott sAC fehérjét a sejtek egyik (indirekt) pH-szenzor molekulájának tartják, amely érzékeny a bikarbonát/ $\mathrm{CO}_{2}$-koncentráció lokális változásaira [67]. Végül érdemes megemlíteni a bikarbonát antimikrobiális tulajdonságait [19]. Egyes tüdőbetegségekben a légúti hámfelszín baktériumölő képessége $\mathrm{NaHCO}_{3}$ beadásával javítható, ami arra utal, hogy a bikarbonát helyreállítja a pH-t és ennek következtében az antimikrobiális peptidek, mint a laktoferrin és a lizozim, aktivitását [49]. A bikarbonát közvetlen antimikrobiális aktivitását is megfigyelték már [15, 17].

\section{A bikarbonát-transzport és a pH-szabályozás szerepe a zománcérés során}

A sav/bázis egyensúly és annak szabályozása kitüntetett szerepet játszik a zománc hidroxiapatit képződésében. A kristálynövekedés nagymértékben függ az extracelluláris folyadék ionösszetételétől és pH-jától, illetve ezek finoman összehangolt szabályozásától [63]. Az ameloblast sejteknek tehát képesnek kell lenniük mind a mineralizációs térben, mind intracellulárisan a sav/bázis egyensúly, a pH szigorú szabályozására. A hidroxiapatit molekula képződése során minden mól hidroxiapatit képződése nyolc mól proton felszabadulását eredményezi. Az amelogenezis érési szakaszában ezért a hidroxiapatit képződése során nagy menynyiségú proton szabadul fel, ami rendkívüli mértékben savasítja a közeget. Ezért, megfelelő pH-szabályozás hiányában, a helyi savas körülmények egyértelműen megakadályoznák a kalcium és foszfát további precipitációját, amelynek következtében a mineralizációs folyamat leállna. Így a kristálynövekedés fenntartása érdekében ezeket a protonokat folyamatosan semlegesíteni kell, bikarbonát zománctérbe történő kiválasztásával [27, 31, 36, 56, 66]. (1. B kép)

A légző- és az emésztőrendszer minden szakaszán találhatók pH-szabályozást és/vagy bikarbonát-szekréciót ellátó epithelialis eredetű sejtek. Ezek jól meghatározott, általában az Slc4, Slc12, Slc26, és ABC transzporter fehérjecsaládokból kikerülő ioncsatornákat és transzporter membránfehérjéket múködtetnek a $\mathrm{H}^{+}$és $\mathrm{HCO}_{3}^{-}$ionok irányított „mozgatására”. Az utóbbi évtizedben több ilyen, a pH- szabályozásban potenciálisan szerepet játszó transzporter fehérjét mutattak ki ameloblast sejtekben is [30,65].

A pH-szabályozás zománcfejlődésben játszott szerepének fontosságát mutatja, hogy számos esetben mutatták ki bizonyos zománcfejlődési zavarok hátterében egy-egy pH-szabályozásban érintett transzportfehérje mutációját [16, 68]. Emellett számos ilyen transzportfehérje jelentősége nyert igazolást génkiütéses egér-modellek immunhisztológiai vizsgálatai során. Így a CFTR klorid-csatorna [1, 3, 61, 69, 70], az anion-cserélö-2 (AE2) [36], az elektrogén $\mathrm{Na}^{+}-\mathrm{HCO}_{3}^{-}$kotranszporter-1 (NBCe1) [32], a Na $/ \mathrm{H}^{+}$cserélő-1 (NHE1), a szénsavanhidráz 2 és 6 (CA2, CA6), a pendrin (SLC26A4), DRA (SLC26A3) és a Pat1 (SLC26A6) transzporter fehérjék [26, 71] jelenlétét mind kimutatták az ameloblast sejtek szekréciós és/vagy érési stádiumaiban. (1. kép) Ezen transzportfehérjék müködési zavarai bizonyítottan károsítják a sima és fodros felszínú ameloblast egymásba alakulását, és befolyásolják a normális zománcérést [11, 27, 33, 34]. Ez a megfigyelés arra utal, hogy a mineralizációs térben a pH-nak kiemelkedő szerepe van az ameloblast müködés irányításában, amelynek során a sima felszínű sejtek fodros felszínű sejtekké alakulnak az érési szakaszban. Az ameloblast funkciók sérült, hibás szabályozása késleltetheti a mineralizációs 
folyamat végbemenetelét, és a fog előtörése után sérülékeny, hipomineralizált zománcot eredményezhet.

A zománcképződés során a sav/bázis szabályozásra vonatkozó adatok még ellentmondásosak [6, 11, 29]. Nyilvánvaló azonban, hogy az ameloblastoknak megfelelő molekuláris apparátussal kell rendelkezniük a bikarbonát-ionok szekréciójához a zománctérbe, hogy semlegesíteni tudják a hidroxiapatit-képződés során felszabadult protonokat [65].

\section{A pH-szabályozásban potenciálisan fontos szerepet betöltő iontranszport mechanizmusok}

Az AE2 és CFTR mellett az ameloblastok az extracelluláris és intracelluláris $\mathrm{pH}$ változásait az elektrogén $\mathrm{Na}^{+}-\mathrm{HCO}_{3}{ }^{-}$kotranszporter-1 (NBCe1), a Na+$/ \mathrm{H}^{+}$cserélő-1 (NHE1), a szénsav-anhidráz 2 és 6 (CA2, CA6), a pendrin (SLC26A4), DRA (SLC26A3) és Pat1 (SLC26A6) transzporter fehérjék által is szabályozzák [11, 26, 27, 31, 33, 34]. (1. kép)

A nátrium-bikarbonát kotranszporter (SLC4A4/NBCe1) a nátrium- és bikarbonát-ionok egyidejü, egyirányú, elektrogén, azaz töltésváltozással is járó transzportját valósítja meg, így számos szerv epithel sejtjeiben (pl. hasnyálmirigy duktusz vagy nyálmirigy acinus és duktusz sejtekben) ellátja a bikarbonát keringési oldalról történő felvételét. Az NBCe1 transzporter fehérjének fontos szerepe van a zománcérés során is. Defektusa a zománcfejlődés épségét súlyosan érinti mind egérben, mind emberben [21, 24, 32]. Paine és mtsai szekréciós ameloblastok basolateralis membránjában mutatták ki egerekben [46]. Lacruz és mtsai megfigyelték az NBCe1 transzporter expressziójának növekedését érési ameloblast sejtekben is [32]. (1. B kép)

$\mathrm{Az}$ anion-cserélők elengedhetetlen szerepére is vannak bizonyítékaink. Köztük a legtöbb adat a klorid-bikarbonát cserélő SLC4A2/AE2 transzporterről áll rendelkezésre. Ezek a klorid- és bikarbonát-ionok ellentétes irányú transzportját végzik, és a legtöbb epithelsejt véroldali, azaz bazolaterális membránjában kifejeződnek. Az AE2 transzporter defektusa súlyos zománcszerkezeti és fogfejlődési rendellenességeket okoz, ahogy azt különböző génkiütéses egérmodellekben megfigyelték [10, 36]. Legnagyobb mértékben az érési ameloblastok bazolaterális membránjában jelenik meg [10, 27]. (1. B kép)

$A z$ utóbbi években egy másik anion-cserélő fehérjecsalád tagjainak zománcérésben játszott lehetséges szerepéről is felbukkantak adatok. Az SLC26A családba tartozó pendrin/SLC26A4, PAT1/SLC26A6 és SUT2/SLC26A7 transzporterek szintén a klorid- és bikarbonát-ionok cseréjét teszik lehetővé. (1. B kép) Ezeket is elsősorban érési fázisú ameloblastokban mutatták ki [71], de jelentőségük még nem világos, ugyanis az egyes transzporterek génkiütéses modelljei nem okoztak jelentős fenotípus-változást a zománcban [5, 26, 71]. Ennek oka az lehet, hogy ezek az anion-cse- rélők kiegészítik egymást, képesek a másik funkciókiesését kompenzálni [26]. Az SLC26A1 és SLC26A7 hiányában az SLC26A9 és más transzporterek, ioncsatornák (CFTR, CA2, NBCe1) kifejeződése megnő [71]. Az SLC26A6 és SLC26A7 anion-cserélők hiánya állatokban a sav-bázis egyensúly súlyos szabályozási zavarát okozza [71]. Hasonló apikális eloszlást mutatnak, mint a CFTR, azaz a $\mathrm{Cl}^{-}$és $\mathrm{HCO}_{3}{ }^{-}$transzportra egyaránt képes anion-csatorna. Ameloblastokban is valószínúleg a sejtek apikális pólusán vesznek részt a bikarbonát leadásában, szekréciójában, a CFTR csatornával együttmüködve [5, 71].

A CFTR (cisztás fibrózis transzmembrán konduktancia regulátor) egy ABC-transzporterek (ATP-kötő kazetta transzporterek) családjába tartozó, ciklikus-AMP (cAMP) által regulált klorid-csatorna. Az emberi szervezetben széleskörüen expresszálódik szekréciós epithel sejtek (pl. különböző mirigyhám sejtek) apikális membránjában. Mutációi a folyadék-transzport zavarához vezetnek, komoly betegséget okozva a tüdőben, a hasnyálmirigyben és más szervekben (cisztás fibrózis). A CFTR-csatorna immunhisztokémiai módszerrel kimutatható érési fázisú ameloblastok apikális membránjában [3], és a késői érési fázisban jelentősen emelkedett az expressziója a szekréciós fázishoz képest [34]. (1. B kép)

CFTR génkiütött (CF) egerekben a késői szekréciós, illetve a korai érési fázisú ameloblastok morfológiája megváltozik [69, 70]. A zománc normális vastagságú, de porózusabb és kevésbé mineralizált, továbbá a fogzománc $\mathrm{Cl}^{-}$-tartalma alacsonyabb [1, 69]. A CFTR az ameloblastokban az apikális, azaz a mineralizációs oldalon fejeződik ki, a növekvő zománckristályok közvetlen közelében. Valószínúleg a klorid-ionok leadása a feladata [3], minden bizonnyal közvetlenül vagy közvetve bikarbonát-transzporttal kapcsoltan [23].

\section{Funkcionális in vitro vizsgálatok a transzporterek szerepének igazolására}

Az elmúlt években munkacsoportunk létrehozott az epithelialis transzportfolyamatok molekuláris szintű vizsgálatát lehetővé tévő kétdimenziós in vitro modellt. Ennek központi eleme a permeábilis membránra ültetett, differenciáltatott HAT-7 sejtek, amely egy patkánymetszőfogból izolált preameloblast eredetű sejtvonal. A Transwell membrán a tápfolyadék ion és fehérje alkotóit átengedi, de a sejteket nem. A membránon növesztett HAT-7 sejtekből szoros kapcsolatokkal zárt sejtréteget tudtunk létrehozni. A sejtréteg két oldalán így két elkülönült (apikális és bazolaterális) térfél alakul ki, amely térfelek között az ionok számára csak a sejtrétegen keresztül lehetséges „átjárás”, és ionmozgás csak a fehérjék által szabályozottan tud megvalósulni. A sejteket egy pH-érzékeny fluorescens festékkel feltöltve (BCECF), majd a különböző térfeleken különböző összetételű oldatokat áramoltatva egy speciális mikro- 
szóppal, mikrofluorimetriás módszerrel valós időben követhetőek az intracelluláris $\mathrm{pH}$-változások, azaz a $\mathrm{H}^{+}$és $\mathrm{HCO}_{3}{ }^{-}$ionok transzportja. 2016-ban publikált tanulmányunk fő megállapítása az volt, hogy a Transwell membránokon egy rétegben növesztett HAT-7 sejtek képesek az apikális-bazolaterális $\mathrm{HCO}_{3}{ }^{-}$szekrécióra [2]. A továbbiakban azt vizsgáltuk, hogy ebben a folyamatban milyen fehérjék játszanak szerepet. $A$ bikarbonát szekréciójához szükség van előzetesen $\mathrm{HCO}_{3}{ }^{-}$sejten belüli felhalmozására különböző transzportmechanizmusok útján. Az ebben feltehetően kulcsszerepet játszó bazolaterális oldali sav/bázis transzporterek azonosítása céljából először megvizsgáltuk a sejtekben az intracelluláris $\mathrm{pH}\left(\mathrm{pH}_{\mathrm{i}}\right)$ helyreállási képességét savas terhelés után, $\mathrm{HCO}_{3}^{-}-\mathrm{t}$ és $\mathrm{CO}_{2}$-t nem tartalmazó környezetben.

A sejtek az intracelluláris pH-t szigorú keretek között szabályozzák, állandó értéken tartják, ezért a pH-szabályozásért felelős transzporterek vizsgálatához a pHegyensúlyt drasztikusan megzavaró külső beavatkozásokat kell végeznünk. A leggyakoribb módszerek a jelentős intracelluláris savasodást/alkalizációt („savas terhelést”) okozó reagensek alkalmazása (pl. az ammónium-pulzus technika), és valamely, a transzportfolyamatok szempontjából fontos, meghatározó ion (pl. $\mathrm{Na}^{+}, \mathrm{Cl}^{-}, \mathrm{HCO}_{3}^{-}$) extracelluláris megvonása. Ez az érintett transzporterek múködését megakadályozza, és az iontranszport irányát megváltoztatja.

Eredményeink szerint a savas terhelésre bekövetkező kompenzációs $\mathrm{pH}_{\mathrm{i}}$-emelkedés a basolaterális $\mathrm{Na}^{+}$-tól függ . Így ezt nagy mértékben blokkolták a bazolaterálisan adott $\mathrm{Na}^{+} / \mathrm{H}^{+}$cserélőket specifikusan gátló szerek [51]. Ez összhangban áll azzal a megfigyeléssel, hogy a gyomor-bél traktus különféle hámsejtjeinek szinte egyetemes tulajdonsága egy bazolaterálisan megjelenő $\mathrm{Na}^{+} / \mathrm{H}^{+}$ cserélő, az NHE1. (1. A és $B$ kép)

A HAT-7 sejtes vizsgálatainkban a bazolaterális $\mathrm{Na}^{+}-\mathrm{HCO}_{3}{ }^{-}$-kotranszporter jelenlétét $\mathrm{HCO}_{3}{ }^{-} / \mathrm{CO}_{2}$ jelenlétében végzett savas terheléses kísérletekben mutattuk ki [51]. A Na${ }^{+} / \mathrm{H}^{+}$cserélő és a $\mathrm{Na}^{+} / \mathrm{HCO}_{3}{ }^{-}$kotranszporter gátlószereinek, egyidejú alkalmazása szignifikánsan nagyobb gátlást eredményezett, mint a $\mathrm{Na}^{+} / \mathrm{H}^{+}$cserélő gátlószere önmagában alkalmazva. Ez arra utal, hogy egy bazolaterális nátrium-bikarbonát-kotranszporter is hozzájárul az intracelluláris $\mathrm{HCO}_{3}^{-}$utánpótláshoz [51]. (1. B kép)

Amikor az $\mathrm{NHE}$ aktivitást $\mathrm{HCO}_{3}{ }^{-}$-mentes közegben mértük, a $\mathrm{pH}_{\mathrm{i}}$-visszatérés sebessége az acidózisból és annak NHE-inhibitorral való gátlása lényegesen alacsonyabb volt, mint a $\mathrm{HCO}_{3}^{-}$-tartalmú közegben mért viszszatérés és gátlása, újra jelezve egy NHE-független mechanizmus létezését [51].

A nátrium-kálium-klorid kotranszporter (NKCC) aktivitás is kimutatható mikrofluorometriával, $\mathrm{NH}_{4} \mathrm{Cl}$ tartalmú oldat alkalmazásával. A nátrium-kálium-klorid kotranszporter a $\mathrm{K}^{+}$helyett $\mathrm{NH}_{4}{ }^{+}$-ionokat is képes bejuttatni a sejtbe [48]. A gyengén savas $\mathrm{NH}_{4}{ }^{+}$ionok mozgása $\mathrm{pH}-$ változást okoz, mivel a sejtbe jutva proton donorként viselkedik, s ez pH-csökkenést okoz a sejtben. Kísérleteink során a polarizált HAT-7 sejtek $\mathrm{NH}_{4} \mathrm{Cl}$ expozíciója alatt egy szignifikáns bazolaterális, az NKCC gátlószerére érzékeny $\mathrm{pH}_{\mathrm{i}}$ csökkenést figyeltünk meg [51]. (1. B kép)

$\mathrm{Cl}^{-}$ion szubsztitúciós kísérleteink szerint a HAT-7 sejtek bazolaterális membránjában funkcionális $\mathrm{Cl}^{-} /$ $\mathrm{HCO}_{3}{ }^{-}$-cserélő aktivitás detektálható [51]. Ez az ioncserélő valószínűleg az AE2 transzporter, amelynek expresszióját polarizált HAT-7 sejtjeinkben immunocitokémiával is kimutattuk [2]. Ez a transzporter a legtöbb epithelialis sejt bazolaterális membránjában is jelen van [54]. (1. A kép)

\section{Az ameloblastok pH-szabályozásában szerepet játszó fő iontranszport-folyamatok feltételezett rendszere}

A CO${ }_{2} / \mathrm{HCO}_{3}{ }^{-}$egyensúly fenntartásáért felelős transzportfehérjéknek központi szerepe van az ameloblast sejtek egy nagyon fontos funkciójában: nevezetesen abban, hogy az extracelluláris $\mathrm{pH}$-t a mineralizációs térben megfelelően szabályozzák [9, 31, 33, 34]. Fiziológiás körülmények között, $\mathrm{HCO}_{3}{ }^{-}$és $\mathrm{CO}_{2}$ jelenlétében, az $\mathrm{NHE1}$ transzporter hozzájárul a bikarbonát felhalmozódásához a sejtekben, mivel elmozdítja a szénsav-anhidrázok által katalizált reakciót a $\mathrm{HCO}_{3}{ }^{-}$-ionok képződése felé azáltal, hogy a $\mathrm{H}^{+}$-ionokat eltávolítja a sejtből [51]. $\mathrm{A} \mathrm{H}^{+}$leadás mechanizmusa mellett a $\mathrm{Na}^{+}-\mathrm{HCO}_{3}^{-}-\mathrm{ko}^{-}$ transzporterek (NBC-k) szintén hozzájárulnak a $\mathrm{HCO}_{3}^{-}$ sejten belüli felhalmozódásához a $\mathrm{HCO}_{3}{ }^{-}$közvetlen felvételével. (1. kép) Ezt támasztják alá a HAT-7 sejtekben végzett RT-PCR-vizsgálataink eredményei az NBCe1 expressziójára vonatkozóan [2] és a szakirodalomban megjelent, az érési fázisú ameloblast sejtekre vonatkozó immunhisztokémiai adatok is [26]. Az NBCe1 bazolaterális lokalizációja ezekben az ameloblast sejtekben hasonló a patkány [73] és tengerimalac hasnyálmirigyduktusz sejtekben [22], valamint patkány [18] és tengerimalac nyálmirigyek szekréciós hámsejtjeiben leírtakhoz [35]. (1. B kép)

Szekréciós hámokban a $\mathrm{HCO}_{3}{ }^{-}$transzport folyamatok végrehajtásához általában a klorid-ionok megfelelő transzportjára is szükség van [12]. Ezek a zománcképződés során is hasonlóan fontos szerepet játszanak; minden jel szerint nélkülözhetetlenek a pH-szabályozásában is [4]. Állatkísérletekben erős, pozitív korrelációt figyeltek meg a zománc alapállományának kalcium- és a klorid-tartalom változásai között, a zománcérés és az érési ameloblastok két formájának ciklikus egymásba alakulása során. A normál értéknél alacsonyabb $\mathrm{Cl}^{-}$tartalom hipomineralizációhoz vezetett [8]. Az a megfigyelés is sokatmondó, hogy a CFTR-hiányos és az AE2hiányos egerek fogainak zománcszerkezetében jelentős hipomineralizációs elváltozások figyelhetők meg [8, 61].

Lényeges körülmény, hogy a $\mathrm{Cl}^{-}$ionoknak először intracellulárisan kell felhalmozódniuk a sejtekben, annak 
érdekében, hogy az apikális membránon keresztül szekretálódhassanak. $\mathrm{A} \mathrm{Cl}^{-}$ionok felvételét biztosítani képes transzportfehérjék a nátrium-kálium-klorid kotranszporterek (NKCC-k). Az NKCC-k olyan egyirányú transzporterek, amelyek a $\mathrm{Na}^{+}, \mathrm{K}^{+}$és $\mathrm{Cl}^{-}$ionokat egyidejúleg a sejtbe juttatják szekunder aktív transzport útján. (1. $B$ kép) Ezért az NKCC1 transzporter feltehetően fontos szerepet játszik az ameloblast sejtek bazolaterális oldali $\mathrm{Cl}^{-}$ felvételében, hasonlóan számos más szekréciós epitheliumban leírtakhoz is [12, 62], [13], ahol a $\mathrm{Cl}^{-}$-szekréció nagyban függ a bazolaterális NKCC1 aktivitástól [38, 47]. Mi szolgáltattuk az első funkcionális bizonyítékot arra, hogy az NKCC1 szerepet játszhat az ameloblastok $\mathrm{Cl}^{-}$ akkumulációjában. Ez azzal az új immunhisztokémiai megfigyeléssel is összecseng, mely szerint az ameloblastok működését közvetlenül támogató papilláris sejtekben is kifejeződik az NKCC1 az amelogenezis során [25].

A bikarbonát transzporterek másik fő csoportja az anion-cserélők (AE). Az Slc4 fehérjecsalád $\mathrm{Na}^{+}$-független anion-cserélő tagjai a $\mathrm{Cl}^{-}$és $\mathrm{HCO}_{3}{ }^{-}$ionok cseréjét valósítják meg a sejt belseje és extracelluláris tér között. (1. A kép) A nyálmirigy acinus sejtekben például a bazolaterális $\mathrm{Cl}^{-} / \mathrm{HCO}_{3}{ }^{-}$kicserélő az iontranszportmechanizmusok egy lényeges eleme, amely egy fontos útvonalat biztosít a $\mathrm{Cl}^{-}$ionok gradienssel szemben történő intracelluláris felhalmozódásához [13, 38]. Az AE transzporterek bazolaterális elhelyezkedése az ameloblast eredetű HAT-7 sejtekben összhangban áll a korábbi irodalmi adatokkal is, amelyek immunhisztokémiai vizsgálatokkal kimutatták az AE2 bazolaterális jelenlétét érési ameloblast sejtjekben [36, 37].

Fentiekre alapozva és saját funkcionális eredményeinkre is támaszkodva feltételezzük, hogy az érési ameloblastok ciklizálása során a következő folyamatok zajlanak le:

A fodros felszínű ameloblast sejtek szekretálják a $\mathrm{Ca}^{2+}$ és foszfát ionokat a zománctérbe. A sejt $\mathrm{Ca}^{2+}$ felvétele a bazolaterális oldalon történik, a store operated calcium felvételi útvonalon (SOCE) keresztül, majd a $\mathrm{Ca}^{2+}$ az apikális felszínen a kálium-függő nátrium/kalcium cserélő (NCKX4) és nátrium/kalcium cserélő (NCX, transzporterek) segítségével ürül ki. A foszfátszállítás valószínűleg a $\mathrm{Na}^{+}$-függő foszfáttranszporteren keresztül történik. Eközben a mineralizáció fokozódásával párhuzamosan, a mineralizációs térben a pH lassú csökkenése figyelhető meg, mivel a hidroxiapatit kristályok képződése közben nagy mennyiségű proton szabadul fel (1 mól kristályképződés során 8 mól proton felszabadulás történik), amelyhez feltételezhetően egy aktív folyamat is hozzájárul, amelyben a V-H+-ATPáz (V típusú, vagy vakuoláris ATPáz) játszik szerepet az apikális oldalon [52]. (1. A kép)

A sima felszínű érési ameloblastok a bazolaterális oldalra építik át a szoros kapcsolatokat. (1. B kép) Az intracelluláris bikarbonát felhalmozódását a bazolaterálisan zajló $\mathrm{Na}^{+} / \mathrm{HCO}^{-}$kotranszport és a $\mathrm{Na}^{+} / \mathrm{H}^{+}$cserélőn keresztül megvalósuló, szénsav-anhidrázzal támogatott proton-kiválasztás idézi elő [52]. (1. B kép) A Na+ jelenlététől függő nátrium-proton cserélők a protonok bazolaterális oldali leadásával a bikarbonát intracelluláris akkumulációját biztosíthatják. (1. B kép) A nátrium-bikarbonát kotranszporter bazolaterális aktivitása a bikarbonát-ionok közvetlen transzportjához járulhat hozzá. A bazolaterális anion-cserélő aktivitás pedig fontos eleme lehet az ameloblast sejtek pH-szabályozásának mind a sejten belül, mind a mineralizációs térben.

Az intracelluláris $\mathrm{Cl}^{-}$felhalmozódást valószínúleg a nátrium-kálium-klorid kotranszporter végzi, amelynek fő mozgatója a $\mathrm{Na}^{+} / \mathrm{K}^{+}$ATPáz generálta $\mathrm{Na}^{+}$grádiens. (1. $B$ kép) Apikálisan a klorid és kisebb mennyiségben a bikarbonát a cAMP-aktiválta CFTR és a $\mathrm{Ca}^{2+}$-aktivált klorid csatornákon keresztül hagyja el az ameloblast sejteket. (1. B kép) A bikarbonát apikálisan az ezt megelőzően szekretált kloridionnal cserélődik ki az SLC26A anioncserélő segítségével [52]. (1. B kép)

A ciklikus átalakulás a fodros felszínúből a sima felszínű sejtalakba és a pH-szabályozás képessége a mineralizációs térben együttesen lehetővé teszik a folyamatos hidroxiapatit kristálynövekedést, amíg az eléri a legvégső, 95\% feletti mineralizáltságú szintet [52]. (2. kép)

\section{Nátrium-fluorid hatása a bikarbonát-szekrécióra}

A fenti iontranszport-vizsgálatokhoz kapcsolódnak a fluorid zománcképződést befolyásoló mechanizmusával kapcsolatos megfigyeléseink. Jól ismert jelenség, hogy a nagy dózisú fluorid-expozíció a fogfejlődés során gátolja a zománcképződést, és hipomineralizált zománc kialakulásához vezet $[7,14,59]$. A pontos mechanizmus nagyrészt még ismeretlen, valószínúleg a dózistól és az ameloblastok érési stádiumától függően egyszerre több tényező is hozzájárulhat a jelenség kialakulásához. Így a fluorid befolyásolhatja az ameloblast sejtek ionszekrécióját, de az ameloblastok különböző fejlődési és funkcionális állapotait is, amelyek nincsenek közvetlen összefüggésben az ionszekrécióval. Emellett a fluorid közvetlenül is hatással lehet a mineralizáció egyes fizikai történéseire.

Saját kísérleteinkben azt vizsgáltuk, hogy a fluoridexpozíció befolyásolja-e a HAT-7 sejtek transzcelluláris $\mathrm{HCO}_{3}{ }^{-}$szekrécióját. Korábbi közleményünkben [2] kimutattuk, hogy a HAT-7 sejtek képesek $\mathrm{HCO}_{3}{ }^{-}$ionokat felvenni a bazolaterális membránon keresztül, majd ezután apikálisan szekretálni. Vizsgálati adataink egyértelműen azt mutatják, hogy a fluorid akut expozíciója egy széles koncentráció-tartományban nem okoz változást a HAT-7 sejtek $\mathrm{HCO}_{3}^{-}$felvétel blokkolásával kiváltott acidifikációjának sebességében, ugyanakkor NaF adása lassítja a sejtek polarizációjához szükséges szoros kapcsolatok kialakulását, mindezt olyan dózisokban, amelyek nem citotoxikusak az ameloblast eredetú HAT-7 sejtekre $[51,65]$. 


\section{Következtetés}

A pH-szabályozás fontos az ameloblastok zománcképző működése során, ez összhangban áll saját vizsgálati eredményeinkkel is. Az amelogenezis érési szakaszában a hidroxiapatit képződése nagy mennyiségú proton felszabadulásával jár együtt, ezért a megfelelő pH-szabályozás hiányában az így savassá váló környezet megakadályozza a kalcium és foszfát ionok további lerakódását, ezzel a mineralizációs folyamat leállását okozza. Következésképp a kristálynövekedés fenntartása érdekében ezeket a protonokat semlegesíteni kell bázikus ionok, elsősorban bikarbonát mineralizációs térbe történő kiválasztásával. Ennek megfelelően az ameloblastok befolyásolni tudják az extracelluláris és intracelluláris $\mathrm{pH}$-változásait a $\mathrm{Na}^{+}-\mathrm{HCO}_{3}{ }^{-}$kotranszporter-1 (NBCe1), a Na $/ \mathrm{H}^{+}$cserélő-1 (NHE1), az anion cserélö-2 (AE2), a CFTR, a szénsav-anhidráz 2 és 6 (CA2, CA6), a pendrin (SLC26A4), DRA (SLC26A3) és Pat1 (SLC26A6) transzporter fehérjék expresszióján és múködésén keresztül.

\section{Irodalom}

1. Arquitt CK, Boyd C, Wright JT: Cystic fibrosis transmembrane regulator gene (cftr) is associated with abnormal enamel formation. J Dent Res 2002; 81: 492-496. https://doi.org/10.1177/154405910208100712

2. Bori E, Guo J, Racz R, Burghardt B, Foldes A, Keremi B, et al: Evidence for bicarbonate secretion by ameloblasts in a novel cellular model. J Dent Res 2016; 95: 588-596. https://doi.org/10.1177/0022034515625939

3. Bronckers A, Kalogeraki L, Jorna HJ, Wilke M, Bervoets TJ, LYARUU DM, et al: The cystic fibrosis transmembrane conductance regulator (cftr) is expressed in maturation stage ameloblasts, odontoblasts and bone cells. Bone 2010; 46: 1188-1196. https://doi.org/10.1016/j.bone.2009.12.002

4. BRONCKERS AL: Ion transport by ameloblasts during amelogenesis. J Dent Res 2017; 96: 243-253. https://doi.org/10.1177/0022034516681768

5. Bronckers AL, Guo J, Zandieh-Doulabi B, Bervoets TJ, Lyaruu DM, LI X, et al: Developmental expression of solute carrier family $26 \mathrm{a}$ member 4 (slc26a4/pendrin) during amelogenesis in developing rodent teeth. Eur J Oral Sci 2011; 119 (Suppl 1): 185-192. https://doi.org/10.1111/j.1600-0722.2011.00901.x

6. Bronckers AL, Lyaruu DM, Bervoets TJ, Medina JF, Denbesten P, RICHTER J, et al: Murine ameloblasts are immunonegative for tcirg1, the $v$-h-atpase subunit essential for the osteoclast plasma proton pump. Bone 2012; 50: 901-908.

https://doi.org/10.1016/j.bone.2011.12.019

7. Bronckers AL, LyARUu DM, DenBesten PK: The impact of fluoride on ameloblasts and the mechanisms of enamel fluorosis. J Dent Res 2009; 88: 877-893. https://doi.org/10.1177/0022034509343280

8. Bronckers AL, Lyaruu DM, Guo J, Bijvelds MJ, Bervoets TJ, ZaNDIEH-DoulabI B, et al: Composition of mineralizing incisor enamel in cystic fibrosis transmembrane conductance regulatordeficient mice. Eur J Oral Sci 2015; 123: 9-16. https://doi.org/10.1111/eos.12163

9. Bronckers AL, Lyaruu DM, Jalali R, Denbesten PK: Buffering of protons released by mineral formation during amelogenesis in mice. Eur J Oral Sci 2016; 124: 415-425. https://doi.org/10.1111/eos.12287
10. Bronckers AL, Lyaruu DM, Jansen ID, Medina JF, Kellokumpu $S$, HoEbEN KA, et al: Localization and function of the anion exchanger ae2 in developing teeth and orofacial bone in rodents.

J Exp Zool B Mol Dev Evol 2009; 312B: 375-387. https://doi.org/10.1002/jez.b.21267

11. Damkier HH, Josephisen $K$, Takano $Y, Z$ ahn $D$, Fejerskov $O$, FRISCHE S: Fluctuations in surface $\mathrm{pH}$ of maturing rat incisor enamel are a result of cycles of $\mathrm{H}(+)$-secretion by ameloblasts and variations in enamel buffer characteristics. Bone 2014; 60: 227-234. https://doi.org/10.1016/j.bone.2013.12.018

12. Demeter I, Hegyesi O, Nagy AK, Case MR, Steward MC, Varga G, et al: Bicarbonate transport by the human pancreatic ductal cell line hpaf. Pancreas 2009; 38: 913-920. https://doi.org/10.1097/MPA.0b013e3181b32c08

13. Demeter I, Szücs A, Hegyesi O, Földes A, Rácz GZ, Burghardt B, et al: Vectorial bicarbonate transport by par-c10 salivary cells. J Physiol Pharmacol 2009; 60 Suppl 7: 197-204.

14. Denbesten PK, Crenshaw MA, Wilson MH: Changes in the fluoride-induced modulation of maturation stage ameloblasts of rats. J Dent Res 1985; 64: 1365-1370. https://doi.org/10.1177/00220345850640120701

15. Dobay O, Laub K, Stercz B, Keri A, Balazs B, Tothpal A, et al: Bicarbonate inhibits bacterial growth and biofilm formation of prevalent cystic fibrosis pathogens. Front Microbiol 2018; 9: 1-12. https://doi.org/10.3389/fmicb.2018.02245

16. DUAN X: Ion channels, channelopathies, and tooth formation. J Dent Res 2014; 93: 117-125. https://doi.org/10.1177/0022034513507066

17. Gawande PV, Lovetri K, Yakandawala N, Romeo T, Zhanel GG, CVITKOVITCH DG, et al: Antibiofilm activity of sodium bicarbonate, sodium metaperiodate and sds combination against dental unit waterline-associated bacteria and yeast.

J Appl Microbiol 2008; 105: 986-992. https://doi.org/10.1111/j.1365-2672.2008.03823.x

18. Gresz V, Kwon TH, Vorum H, Zelles T, Kurtz I, Steward MC, et al: Immunolocalization of electroneutral na(+)-hco cotransporters in human and rat salivary glands. Am J Physiol Gastrointest Liver Physiol 2002; 283: G473-480. https://doi.org/10.1152/ajpgi.00421.2001

19. Gutierrez-Huante M, Martinez H, Bustamante VH, Puente JL, SANCHEZ J: Bicarbonate enhances the in vitro antibiotic activity of kanamycin in escherichia coli.

Lett Appl Microbiol 2015; 60: 440-446. https://doi.org/10.1111/lam.12388

20. Hu P, Lacruz RS, Smith CE, Smith SM, Kurtz I, Paine ML: Expression of the sodium/calcium/potassium exchanger, nckx4, in ameloblasts. Cells Tissues Organs 2012; 196: 501-509. https://doi.org/10.1159/000337493

21. Inatomi J, Horita S, Braverman N, Sekine T, Yamada H, Suzuki Y, et al: Mutational and functional analysis of slc4a4 in a patient with proximal renal tubular acidosis. Pflugers Arch 2004; 448: 438-444. https://doi.org/10.1007/s00424-004-1278-1

22. Ishiguro $H$, Naruse $S$, Kitagawa M, Suzuki A, Yamamoto $A$, HAYAKAWA T, et al: CO2 permeability and bicarbonate transport in microperfused interlobular ducts isolated from guinea-pig pancreas. J Physiol 2000; 528 (Pt 2): 305-315. https://doi.org/10.1111/j.1469-7793.2000.00305.x

23. Ishiguro H, Steward MC, Naruse S, Ko SB, Goto H, Case RM, et al: Cftr functions as a bicarbonate channel in pancreatic duct cells. J Gen Physiol 2009; 133: 315-326. https://doi.org/10.1085/jgp.200810122

24. Jalali R, Guo J, Zandieh-Doulabi B, Bervoets TJ, Paine ML, Boron WF, et al: Nbce1 (slc4a4) a potential ph regulator in enamel organ cells during enamel development in the mouse. Cell Tissue Res 2014; 358: 433-442. https://doi.org/10.1007/s00441-014-1935-4

25. Jalali R, Lodder JC, Zandieh-Doulabi B, Micha D, Melvin Je, Catalan MA, et al: The role of na:K:2cl cotransporter 1 
(nkcc1/slc12a2) in dental epithelium during enamel formation in mice. Front Physiol 2017; 8: 1-13. https://doi.org/10.3389/fphys.2017.00924

26. Jalali R, Zandieh-Doulabi B, Denbesten PK, Seidler U, Riederer B, WedENOJA S, et al: Slc26a3/dra and slc26a6 in murine ameloblasts. J Dent Res 2015; 94: 1732-1739. https://doi.org/10.1177/0022034515606873

27. Josephsen K, Takano Y, Frische S, Praetorius J, Nielsen S, AовA $\mathrm{T}$, et al: Ion transporters in secretory and cyclically modulating ameloblasts: A new hypothesis for cellular control of preeruptive enamel maturation. Am J Physiol Cell Physiol 2010; 299: C1299-307. https://doi.org/10.1152/ajpcell.00218.2010

28. KALLENBACH E: Fine structure of the stratum intermedium, stellate reticulum, and outer enamel epithelium in the enamel organ of the kitten. J Anat 1978; 126: 247-260.

29. Lacruz RS, Brookes SJ, Wen X, Jimenez JM, Vikman S, Hu P, et al: Adaptor protein complex 2-mediated, clathrin-dependent endocytosis, and related gene activities, are a prominent feature during maturation stage amelogenesis.

J Bone Miner Res 2013; 28: 672-687. https://doi.org/10.1002/jbmr.1779

30. Lacruz RS, Habelitz S, Wright JT, Paine ML: Dental enamel formation and implications for oral health and disease. Physiol Rev 2017; 97: 939-993. https://doi.org/10.1152/physrev.00030.2016

31. Lacruz RS, Nanci A, Kurtz I, Wright JT, Paine ML: Regulation of ph during amelogenesis. Calcif Tissue Int 2010; 86: 91-103. https://doi.org/10.1007/s00223-009-9326-7

32. Lacruz RS, Nanci A, White SN, Wen X, Wang H, Zalzal SF, et al: The sodium bicarbonate cotransporter (nbce1) is essential for normal development of mouse dentition.

J Biol Chem 2010; 285: 24432-24438. https://doi.org/10.1074/jbc.M110.115188

33. Lacruz RS, Smith CE, Kurtz I, Hubbard MJ, Paine ML: New paradigms on the transport functions of maturation-stage ameloblasts. J Dent Res 2013; 92: 122-129. https://doi.org/10.1177/0022034512470954

34. Lacruz RS, Smith CE, Moffatt P, Chang EH, Bromage TG, Bringas P JR, et al: Requirements for ion and solute transport, and $\mathrm{Ph}$ regulation during enamel maturation. J Cell Physiol 2012; 227: 1776-1785. https://doi.org/10.1002/jcp.22911

35. LI J, Koо NY, Chо IH, Kwon TH, Cho SY, Lee SJ, et al: Expression of the na+-hco3- cotransporter and its role in phi regulation in guinea pig salivary glands. Am J Physiol Gastrointest Liver Physiol 2006; 291: G1031-1040. https://doi.org/10.1152/ajpgi.00483.2005

36. Lyaruu dM, Bronckers AL, Mulder L, Mardones P, Medina JF, KeLLokumpu $S$, et al: The anion exchanger ae2 is required for enamel maturation in mouse teeth. Matrix Biol 2008; 27: 119-127. https://doi.org/10.1016/j.matbio.2007.09.006

37. Lyaruu DM, Medina JF, Sarvide S, Bervoets TJ, Everts V, Denbesten $P$, et al: Barrier formation: Potential molecular mechanism of enamel fluorosis. J Dent Res 2014; 93: 96-102. https://doi.org/10.1177/0022034513510944

38. Melvin Je, Yule D, Shuttleworth T, Begenisich T: Regulation of fluid and electrolyte secretion in salivary gland acinar cells. Annu Rev Physiol 2005; 67: 445-469. https://doi.org/10.1146/annurev.physiol.67.041703.084745

39. Nakano Y, Le MH, Abduweli D, Ho SP, Ryazanova LV, Hu Z, et al: A critical role of trpm 7 as an ion channel protein in mediating the mineralization of the craniofacial hard tissues. Front Physiol 2016; 7: 1-11. https://doi.org/10.3389/fphys.2016.00258

40. NANCI A: Ten cate's oral histology: Development, structure, and function. Elsevier, St. Louis, Missouri 2018.

41. Nurbaeva MK, Eckstein M, Concepcion AR, Smith CE, Srikanth S,
PAINE ML, et al: Dental enamel cells express functional soce channels. Sci Rep 2015; 5: 1-10. https://doi.org/10.1038/srep15803

42. Nurbaeva MK, Eckstein M, Devotta A, Saint-Jeannet JP, Yule DI, HubBard MJ, et al: Evidence that calcium entry into calcium-transporting dental enamel cells is regulated by cholecystokinin, acetylcholine and atp. Front Physiol 2018; 9: 1-11. https://doi.org/10.3389/fphys.2018.00801

43. Nurbaeva MK, Eckstein M, Feske S, Lacruz RS: Ca(2+) transport and signalling in enamel cells. J Physiol 2017; 595: 3015-3039. https://doi.org/10.1113/JP272775

44. Nurbaeva MK, Eckstein M, Snead ML, Feske S, Lacruz RS: Store-operated ca2+ entry modulates the expression of enamel genes. J Dent Res 2015; 94: 1471-1477. https://doi.org/10.1177/0022034515598144

45. Okumura R, Shibukawa $Y$, Muramatsu T, Hashimoto S, Nakagawa K, TAZAKI M, et al: Sodium-calcium exchangers in rat ameloblasts. J Pharmacol Sci 2010; 112: 223-230. https://doi.org/10.1254/jphs.09267FP

46. Paine ML, Snead ML, Wang HJ, Abuladze N, Pushikin A, Liu W, et al: Role of nbce1 and ae2 in secretory ameloblasts.

J Dent Res 2008; 87: 391-395. https://doi.org/10.1177/154405910808700415

47. PAULAIS M, TURNER RJ: Activation of the na(+)-k(+)-2cl- cotransporter in rat parotid acinar cells by aluminum fluoride and phosphatase inhibitors. J Biol Chem 1992; 267: 21558-21563. https://doi.org/10.1172/JCl115695

48. PAULAIS M, TURNER RJ: Beta-adrenergic upregulation of the $\mathrm{na}(+)-\mathrm{k}(+)-2 \mathrm{cl}-$ cotransporter in rat parotid acinar cells. J Clin Invest 1992; 89: 1142-1147. https://doi.org/10.1172/JCl115695

49. Pezzulo aA, Tang XX, Hoegger MJ, Abou Alaiwa MH, Ramachandran S, Moninger TO, et al: Reduced airway surface ph impairs bacterial killing in the porcine cystic fibrosis lung. Nature 2012; 487: 109-113. https://doi.org/10.1038/nature11130

50. QUINTON PM: Role of epithelial HCO3(-) transport in mucin secretion: Lessons from cystic fibrosis.

Am J Physiol Cell Physiol 2010; 299: C1222-1233. https://doi.org/10.1152/ajpcell.00362.2010

51. Rácz R, Foldes A, Bori E, Zsembery A, Harada H, Steward MC, et al: No change in bicarbonate transport but tight-junction formation is delayed by fluoride in a novel ameloblast model. Front Physiol 2017; 8: 1-12. https://doi.org/10.3389/fphys.2017.00940

52. Rácz R, Nagy A, Rakonczay Z, Dunavári EK, Gerber G, Varga G: Defense mechanisms against acid exposure by dental enamel formation, saliva and pancreatic juice production. Curr Pharm Des 2018; 24: 2012-2022. https://doi.org/10.2174/1381612824666180515125654

53. RAHMAN N, BUCK J, LEVIN LR: pH sensing via bicarbonate-regulated "soluble" adenylyl cyclase (sac). Front Physiol 2013; 4: 1-5. https://doi.org/10.3389/fphys.2013.00343

54. Romero MF, Fulton CM, Boron WF: The SLC4 family of HCO3- transporters. Pflugers Arch 2004; 447: 495-509. https://doi.org/10.1007/s00424-003-1180-2

55. SASAKI T: Morphology and function of maturation ameloblasts in kitten tooth germs. J Anat 1984; 138 (Pt 2): 333-342.

56. Sмітн CE: Cellular and chemical events during enamel maturation. Crit Rev Oral Biol Med 1998; 9: 128-161. https://doi.org/10.1177/10454411980090020101

57. Smith CE, Issid M, Margolis HC, Moreno EC: Developmental changes in the $\mathrm{pH}$ of enamel fluid and its effects on matrix-resident proteinases. Adv Dent Res 1996; 10: 159-169. https://doi.org/10.1177/08959374960100020701

58. SMITH CE, NANCI A: Protein dynamics of amelogenesis. Anat Rec 1996; 245: 186-207. https://doi.org/10.1002/(SICI)10970185(199606)245:2<186::AID-AR7>3.0.CO;2-V 
59. Smith CE, Nanci A, Denbesten PK: Effects of chronic fluoride exposure on morphometric parameters defining the stages of amelogenesis and ameloblast modulation in rat incisors. Anat Rec 1993; 237: 243-258. https://doi.org/10.1002/ar.1092370212

60. Steed E, Balda MS, Matter K: Dynamics and functions of tight junctions. Trends Cell Biol 2010; 20: 142-149. https://doi.org/10.1016/j.tcb.2009.12.002

61. SUI W, BOYd C, WRIGHT JT: Altered ph regulation during enamel development in the cystic fibrosis mouse incisor. J Dent Res 2003; 82: 388-392. https://doi.org/10.1177/154405910308200512

62. Szücs A, Demeter I, Burghardt B, Ovari G, Case RM, Steward MC, et al: Vectorial bicarbonate transport by capan-1 cells: A model for human pancreatic ductal secretion. Cell Physiol Biochem 2006; 18: 253-264. https://doi.org/10.1159/000097672

63. Takagi T, Ogasawara T, Tagami J, Akao M, Kuboki Y, Nagai N, et al: $\mathrm{Ph}$ and carbonate levels in developing enamel. Connect Tissue Res 1998; 38: 181-187; discussion 201-205. https://doi.org/10.3109/03008209809017035

64. TAKANO Y: Enamel mineralization and the role of ameloblasts in calcium transport. Connect Tissue Res 1995; 33: 127-137. https://doi.org/10.3109/03008209509016992

65. Varga G, Denbesten P, Racz R, Zsembery A: Importance of bicarbonate transport in ph control during amelogenesis - need for functional studies. Oral Dis 2018; 24: 879-890. https://doi.org/10.1111/odi.12738

66. Varga G, Kerémı B, Borı E, Földes A: Function and repair of dental enamel - potential role of epithelial transport processes of ameloblasts. Pancreatology 2015; 15: S55-60. https://doi.org/10.1016/j.pan.2015.01.012

67. Wiggins SV, Steegrorn C, LeVin LR, Buck J: Pharmacological modulation of the $\mathrm{co} 2 / \mathrm{hco} 3(-) / \mathrm{ph}-$, calcium-, and atp-sensing soluble adenylyl cyclase. Pharmacol Ther 2018; 190: 173-186. https://doi.org/10.1016/j.pharmthera.2018.05.008

68. WRIGHT JT, CARRION IA, MorRIS C: The molecular basis of hereditary enamel defects in humans. J Dent Res 2015; 94: 52-61. https://doi.org/10.1177/0022034514556708

69. WRIGHT JT, HALL KI, GRUBB BR: Enamel mineral composition of normal and cystic fibrosis transgenic mice. Adv Dent Res 1996; 10: 270-274; discussion 5. https://doi.org/10.1177/08959374960100022501

70. Wright JT, Kiefer CL, HaLl KI, GrubB BR: Abnormal enamel development in a cystic fibrosis transgenic mouse model. J Dent Res 1996; 75: 966-973. https://doi.org/10.1177/00220345960750041101

71. Yin K, Lei Y, Wen X, Lacruz RS, Soleimani M, Kurtz I, et al: Slc26a gene family participate in ph regulation during enamel maturation. PLoS One 2015; 10: 1-23. https://doi.org/10.1371/journal.pone.0144703

72. ZaKi AE, Hand AR, Mednieks MI, EIsenmann DR, Borke JL: Quantitative immunocytochemistry of $\mathrm{ca}(2+)$-mg2+ atpase in ameloblasts associated with enamel secretion and maturation in the rat incisor. Adv Dent Res 1996; 10: 245-251. https://doi.org/10.1177/08959374960100022101

73. Zhao H, Star RA, Muallem S: Membrane localization of $h+$ and hco3- transporters in the rat pancreatic duct.

J Gen Physiol 1994; 104: 57-85. https://doi.org/10.1085/jgp.104.1.57

Rácz R, Steward CM, DenBesten P, Varga G, Kerémi B

\section{Significance of pH cyclization in amelogenesis}

The process of amelogenesis is well understood at the histomorphological level, but the regulation of crystal formation and the underlying molecular mechanisms are still largely unknown. Ameloblast cells derived from the oral epithelium regulate enamel maturation. In addition to the secretion of matrix proteins and the transport of minerals, $\mathrm{pH}$ regulation is also essential as the formation of hydroxyapatite crystals generates large quantities of $\mathrm{H}+$ ions, which must be neutralized by the secretion of $\mathrm{HCO}^{-}$. During the maturation phase, the phenomenon of $\mathrm{pH}$ cycling is of paramount importance, during which a rearrangement of tight-junctions can also be observed. Genetic or environmental impairment of transport and regulatory processes (e.g. dental fluorosis) leads to the development of enamel defects. To explore these processes, we have developed an in vitro model suitable for functional studies. Central elements of this model are that differentiated ameloblast-derived cells cultured on a permeable membrane express ameloblast-specific protein markers, form tight junctions, become functionally polarized, and are capable of vectorial $\mathrm{HCO}^{-}$secretion. The results of our own experimental work contribute to a better understanding of the molecular mechanism of $\mathrm{pH}$ cycling of ameloblast cells.

Keywords: amelogenesis, ameloblast, dental enamel, bicarbonates, buffers, hidrogen-ion concentration (based on MeHS terms) 